\title{
Control of Glyphosate-Resistant Waterhemp with Two-Pass Weed Control Strategies in Glyphosate/Dicamba-Resistant Soybean
}

\author{
Brittany K. Hedges, Nader Soltani, David C. Hooker, Darren E. Robinson, Peter H. Sikkema \\ University of Guelph, Ridgetown Campus, Ridgetown, Canada \\ Email: soltanin@uoguelph.ca
}

How to cite this paper: Hedges, B.K., Soltani, N., Hooker, D.C., Robinson, D.E. and Sikkema, P.H. (2018) Control of Glyphosate-Resistant Waterhemp with Two-Pass Weed Control Strategies in Glyphosate/Dicamba-Resistant Soybean. American Journal of Plant Sciences, 9, 1424-1432. https://doi.org/10.4236/ajps.2018.97104

Received: May 5, 2018

Accepted: June 16, 2018

Published: June 19, 2018

Copyright $\odot 2018$ by authors and Scientific Research Publishing Inc. This work is licensed under the Creative Commons Attribution International License (CC BY 4.0).

http://creativecommons.org/licenses/by/4.0/ (c) (i) Open Access

\begin{abstract}
Waterhemp is a small-seeded, dioecious, broadleaf weed that emerges throughout the growing season. If left uncontrolled, waterhemp interference can reduce soybean yield up to $73 \%$. Glyphosate-resistant (GR) waterhemp was first discovered in one county in Ontario in 2014; as of 2017, it has been found in two other counties. Glyphosate/dicamba-resistant soybean can be sprayed with glyphosate and/or dicamba preplant (PP), preemergence (PRE) and/or postemergence (POST). The objective of this study was to determine the control of GR waterhemp in glyphosate/dicamba-resistant soybean with PRE residual herbicides, glyphosate/dicamba applied POST or a two-pass program of a PRE residual herbicide followed by glyphosate/dicamba applied POST. At 8 weeks after application (WAA), pyroxasulfone (150 g ai ha $\left.{ }^{-1}\right)$, $S$-metolachlor/metribuzin (1943 $\mathrm{g}$ ai ha $\left.^{-1}\right)$, pyroxasulfone/sulfentrazone (300 g ai ha ${ }^{-1}$ ) and flumioxazin/pyroxasulfone (240 $\mathrm{g}$ ai ha $\left.{ }^{-1}\right)$, applied PRE, resulted in $71 \%, 85 \%, 82 \%$ and $90 \%$ GR waterhemp control, respectively. The same PRE herbicides, followed by glyphosate/dicamba (1800 $\left.\mathrm{g}_{\text {ae }} \mathrm{ha}^{-1}\right)$ POST, improved control to greater than $96 \%$. This study concludes that a two-pass program of an effective soil applied residual herbicide followed by glyphosate/dicamba POST controlled GR waterhemp in glyphosate/dicamba-resistant soybean.
\end{abstract}

\section{Keywords}

Waterhemp, Soybean, Glyphosate Resistance, Glyphosate, Dicamba

\section{Introduction}

Glyphosate is a 5-enolypyruvalshikimate 3-phosphate synthase (EPSPS) inhibitor that provides broad-spectrum weed control [1]. Glyphosate is the most 
widely used herbicide in the world, and controls susceptible waterhemp biotypes up to $30 \mathrm{~cm}$ in height [2]. Currently, there are 41 weed species resistant to glyphosate globally, with four glyphosate-resistant (GR) weed species in Ontario [3]. The weed species resistant to glyphosate in Ontario are waterhemp [( Amaranthus tuberculatus (Moq.) Sauer var. rudis (Sauer) Costea and Tardif], Canada fleabane (Conyza canadensis L. Conq.), common ragweed (Ambrosia artemisiifolia L.) and giant ragweed (Ambrosia trifida L.) [3] [4]. Glyphosate-resistant weeds are prevalent in southern Ontario, and long-term, diversified, integrated weed management strategies need to be developed for the control of GR weeds [5]. Glyphosate-resistant waterhemp was first discovered in Lambton County, Ontario in 2014 [6]. By 2017, GR waterhemp had also been found in Essex County and Chatham-Kent County [5]. All waterhemp populations surveyed in Ontario are resistant to Group 2 herbicides [acetolactate synthase (ALS) inhibitors], and frequently to Group 5 herbicides [photosystem II (PSII) inhibitors]; populations with multiple-sites of resistance decrease the number of herbicides available for controlling this weed species [5] [6] [7]. Globally, waterhemp has been found resistant to six different sites-of-action: groups 2, 4, 5, 9, 14 and 27 [3]. Herbicide resistance to five sites-of-action in one waterhemp biotype has been confirmed [3]. This limits the efficacious herbicides for waterhemp control in some populations.

Waterhemp is a dioecious weed species in the Amaranthus genus that can produce up to 4.8 million seeds per plant when grown in the absence of competition [8]. In the presence of competition, one study reported waterhemp produced an average of 309,000 seeds per plant when it emerged at the time of soybean planting. Waterhemp has been observed to emerge from mid-May until the end of October in Ontario [6] [9]. There is a decrease in waterhemp germination and emergence with an increase in row shading; therefore, herbicides that provide residual control until canopy closure are important for waterhemp control [10]. This highly competitive weed is a major issue in crop production, and when left uncontrolled, can decrease soybean yield as much as 73\% [9]. Schryver et al. [7] studied the efficacy of numerous PRE herbicides for the control of waterhemp in soybean. The most efficacious herbicides were pyroxasulfone (150 $\mathrm{g}$ ai ha ${ }^{-1}$ ), $S$-metolachlor/metribuzin (1943 $\mathrm{g}_{\text {ai ha }}{ }^{-1}$ ), pyroxasulfone/sulfentrazone (300 $\mathrm{g}$ ai $\mathrm{ha}^{-1}$ ) and pyroxasulfone/flumioxazin (240 $\mathrm{g}$ ai ha $\mathrm{ha}^{-1}$ ) which provided 87\%, 93\%, 95\%, 97\% control, respectively, 8 weeks after application (WAA) [7]. Additionally, two-pass herbicide programs of pyroxasulfone (150 $\mathrm{g}$ ai ha ${ }^{-1}$ ) or $S$-metolachlor (1600 $\mathrm{g}_{\text {ai }} \mathrm{ha}^{-1}$ ) applied PRE followed by $(\mathrm{fb})$ fomesafen $(240 \mathrm{~g}$ ai $\mathrm{ha}^{-1}$ ) or acifluorfen (600 $\mathrm{g}$ ai ha ${ }^{-1}$ ) applied postemergence (POST) provided $97 \%$ to $98 \%$ control (Schryver et al. 2017b). Meyer et al. (2016) found that dicamba + $S$-metolachlor + metribuzin $\left(1120+1068+420 \mathrm{~g}\right.$ ae/ai ha $\left.{ }^{-1}\right)$, pyroxasulfone (179 $\mathrm{g}$ ai ha $\left.{ }^{-1}\right)$, and pyroxasulfone + flumioxazin $\left(70+89 \mathrm{~g}^{\text {ai ha }} \mathrm{ha}^{-1}\right)$ controlled GR waterhemp 96\%, 96\% and 97\%, respectively, $4 \mathrm{WAA}$, in the absence of crop competition. At 8 WAA, pyroxasulfone (89 - $179 \mathrm{~g}^{\text {ai ha }}{ }^{-1}$ ) controlled GR wa- 
terhemp 78\% [11]. Sarangi et al. [12] reported an increase in control and decrease in density and biomass of waterhemp with a PRE fb POST program compared to a two-pass POST program. Sequential applications of glyphosate (560 $860 \mathrm{~g}$ ae $\left.\mathrm{ha}^{-1}\right)+$ dicamba $\left(280-860 \mathrm{~g}\right.$ ae ha $\left.{ }^{-1}\right)$ applied 4 to 7 days apart controlled $7.5 \mathrm{~cm}$ tall GR waterhemp 72\% [13]. In general, two-pass herbicide programs have provided more consistent control of GR waterhemp.

Glyphosate/dicamba-resistant soybean (Roundup Ready $2 \mathrm{Xtend}^{\circledR}$ soybean) is a new biotechnology trait available in Canada that contains transgenes that confer resistance to glyphosate and dicamba. This technology allows for glyphosate and dicamba to be applied preplant (PP), PRE and POST to the soybean crop. In 2017, dicamba was sold alone as Engenia ${ }^{\mathrm{TM}}$, Fexapan ${ }^{\mathrm{TM}}$ or Xtendimax ${ }^{\mathrm{TM}}$ or as a premix of glyphosate/dicamba under the trade name Roundup Xtend ${ }^{\mathrm{TM}}$. New technologies may be important for the control of glyphosate-resistant weeds, as they allow for the use of additional modes-of-action for the control of GR biotypes.

The objective of this study was to evaluate PRE herbicides, POST applications of glyphosate/dicamba, sequential POST applications of glyphosate/dicamba, and a PRE fb glyphosate/dicamba applied POST for the control of GR waterhemp in glyphosate/dicamba-resistant soybean. It is hypothesized that the two-pass programs of a PRE residual herbicide fb glyphosate/dicamba POST will provide the best control of GR waterhemp. This research will add to the existing knowledge on the control of GR waterhemp in Ontario, providing additional options for growers within the province to achieve acceptable control of GR waterhemp.

\section{Materials and Methods}

This study was completed over a two-year period $(2016,2017)$ at three locations in southwestern Ontario for a total of six site-years. Two sites were on Walpole Island, Ontario $(42.592650,-82.476869)$ and the third site was near Cottam, Ontario (42.128549, -82.744135). Each trial consisted of 13 treatments that were arranged in a randomized complete block design with four replications; treatments included a weedy and weed-free control. The six one-pass programs consisted of four different herbicides with residual activity applied PRE and two POST application timings of glyphosate/dicamba. The PRE herbicides were pyroxasulfone (150 g ai ha $\left.{ }^{-1}\right), S$-metolachlor/metribuzin (1943 g ai ha ${ }^{-1}$ ), pyroxasulfone/sulfentrazone (300 $\mathrm{g}$ ai ha ${ }^{-1}$ ), and pyroxasulfone/flumioxazin (240 $\mathrm{g}$ ai $\left.\mathrm{ha}^{-1}\right)$. The POST treatments were glyphosate/dicamba $\left(1800 \mathrm{~g}\right.$ ae ha $\left.{ }^{-1}\right)$ applied early POST (EPOST), or glyphosate/dicamba (1800 $\mathrm{g}$ ae ha ${ }^{-1}$ ) applied late POST (LPOST). The five two-pass programs consisted of glyphosate/dicamba applied EPOST fb glyphosate/dicamba LPOST, and the above residual herbicides applied PRE fb glyphosate/dicamba LPOST. The PRE herbicides were applied after seeding soybean and before crop emergence; the EPOST herbicide applications were when waterhemp plants were up to $10 \mathrm{~cm}$ in height and the LPOST herbicide applications were when there were up to $10 \mathrm{~cm}$ waterhemp escapes 
in the pyroxasulfone treatment. All treatments were applied with a $\mathrm{CO}_{2}$ pressurized backpack sprayer calibrated to deliver $200 \mathrm{~L} \cdot \mathrm{ha}^{-1}$ at $275 \mathrm{kPa}$ through a $1.5 \mathrm{~m}$ boom fitted with four Turbo TeeJet Induction (TTI) nozzles spaced 50 $\mathrm{cm}$ apart (TeeJet Technologies, Wheaton, IL) resulting in $2.0 \mathrm{~m}$ spray width. In crop cover sprays of glyphosate $\left(900 \mathrm{~g}\right.$ ae $\mathrm{ha}^{-1}$ ) were applied as needed to remove the confounding effect of other weed species in the experimental area.

Glyphosate was applied PP at the Walpole sites to control emerged weeds prior to seedbed preparation. Seedbed preparation at all sites was with a double disc followed by a cultivator. Soybean cultivars DKB14-41 and DKB10-01 (Monsanto, Winnipeg, MB) were seeded in 2016 and 2017, respectively, at 400,000 seeds ha ${ }^{-1}$ to a depth of $4 \mathrm{~cm}$. Plots were $2.25 \mathrm{~m}$ wide (3 soybean rows spaced $0.76 \mathrm{~m}$ apart) by $8 \mathrm{~m}$ in length. Trial location, year, seeding date, herbicide application dates and soybean growth stage are presented in Table 1.

Soybean injury and weed control assessments were completed on the same day as the LPOST (WAA) application. Crop injury ratings were taken at 2 and 4 weeks after the LPOST application of glyphosate/dicamba. Injury was rated on a scale of 0 to 100 , where $0 \%$ was no injury and $100 \%$ was soybean death. Visible weed control assessments were completed 2, 4, 8 and 12 WAA of glyphosate/dicamba applied LPOST. Control at 2 WAA was from five site-years instead of six due to human error, and control at 12 WAA was from four site-years since soybean harvest occurred before the 12 WAA rating. Data from glyphosate/dicamba applied LPOST was from 5 site-years, due to waterhemp plants being too tall at time of application for reliable weed control data to be determined. Visible weed control was rated on a scale of 0 to 100 , where $0 \%$ was no control and $100 \%$ was complete control. Waterhemp density and biomass measurements were determined 8 WAA and soybean yield was obtained at maturity. Waterhemp density was measured by counting the number of plants and removing the aboveground biomass in two, $0.25 \mathrm{~m}^{-2}$ subsamples within each plot. Plants samples were dried

Table 1. Trial location, year, seeding date, herbicide application dates, and soybean growth stage at application in Ontario in 2016 and 2017.

\begin{tabular}{cccccccc}
\hline Location & Year & $\begin{array}{c}\text { Seeding } \\
\text { date }\end{array}$ & $\begin{array}{c}\text { PRE } \\
\text { application } \\
\text { date }\end{array}$ & $\begin{array}{c}\text { EPOST } \\
\text { application } \\
\text { date }\end{array}$ & $\begin{array}{c}\text { Soybean } \\
\text { growth } \\
\text { stage }\end{array}$ & $\begin{array}{c}\text { LPOST } \\
\text { application }\end{array}$ & $\begin{array}{c}\text { Soybean } \\
\text { growth } \\
\text { stage }\end{array}$ \\
\hline Walpole 1 & 2016 & 30-May & 03-June & 30-June & V3 & 12-July & V5 \\
Walpole 2 & 2016 & 23-May & 24-May & 09-July & V5 & 17-June & R2 \\
& 2017 & 03-June & 07-June & 15-July & R2 & 03-August & R5 \\
Cottam & 2016 & 30-May & 01-June & 21-June & V2 & 29-June & V4 \\
& 2017 & 19-May & 23-May & 24-June & V3 & 02-July & R2 \\
\hline
\end{tabular}

Abbreviations: PRE, preemergence; EPOST, early POST and LPOST, late POST. 
in a kiln at $60^{\circ} \mathrm{C}$ for two weeks then weighed. In 2017, soybean yield was measured by harvesting two rows of each plot with an Almaco combine (Almaco, Nevada, IL). In 2016, soybean yield was measured from a two $1 \mathrm{~m}$ subsamples from two rows in the plot and threshed using a stationary Almaco thresher. Moisture of soybean seed was adjusted to $14.5 \%$ before analysis.

Statistical analysis was performed using the GLIMMIX procedure in SAS (Ver. 9.4, SAS Institute Inc., Cary, NC). The fixed effect was herbicide treatment, and the random effects were environment (combination of year and location) and block. Herbicide treatment means were separated using the Fisher's protected LSD test and adjusted using Tukey-Kramer. Alpha value was set at $\mathrm{p}=$ 0.05 . The weedy and weed-free control was removed for analysis of visible weed control data; the weed-free control was removed from the waterhemp biomass and density data. PROC UNIVARIATE was used to test residuals for a normal distribution, errors independent of one another and homogeneity. As a result, an arcsine transformation was fit to all visible weed control data and a lognormal distribution with the identity link was fit for waterhemp density and biomass data. Yield data were not transformed. For presentation purposes, all transformed means were back-transformed.

\section{Results and Discussion}

There was no significant soybean injury $(<5 \%)$ in this study (data not presented). The PRE herbicides pyroxasulfone, $S$-metolachlor/metribuzin, pyroxasulfone/sulfentrazone, and pyroxasulfone/flumioxazin controlled GR waterhemp $95 \%$ to $99 \%$ prior to the LPOST application of glyphosate/dicamba. All PRE herbicides provided similar GR waterhemp control. Glyphosate/dicamba (1800 $\mathrm{g} \mathrm{ae} \mathrm{ha}^{-1}$ ) applied EPOST, controlled GR waterhemp by 70\%, which was less than the PRE herbicides used alone (Table 2).

At two locations in 2017 (Walpole 1 and 2), excellent control of waterhemp by the PRE herbicides was observed which delayed LPOST application. The LPOST

Table 2. Means for visible waterhemp control before LPOST application in Ontario in 2016 and 2017.

\begin{tabular}{cccc}
\hline Treatment & $\begin{array}{c}\text { Rate } \\
\left(\mathrm{g} \mathrm{ai} / \mathrm{ae} \mathrm{ha}^{-1}\right)\end{array}$ & $\begin{array}{c}\text { Application } \\
\text { timing }\end{array}$ & $\begin{array}{c}\text { Control (\%) at } \\
\text { LPOST app. }{ }^{\mathrm{ab}}\end{array}$ \\
\hline $\begin{array}{c}\text { Glyphosate/dicamba } \\
\text { Pyroxasulfone }\end{array}$ & 1800 & EPOST & $70 \mathrm{~b}$ \\
$S$-metolachlor/metribuzin & 150 & PRE & $95 \mathrm{a}$ \\
Pyroxasulfone/sulfentrazone & 1943 & PRE & $99 \mathrm{a}$ \\
Pyroxasulfone/flumioxazin & 300 & PRE & $98 \mathrm{a}$ \\
\hline
\end{tabular}

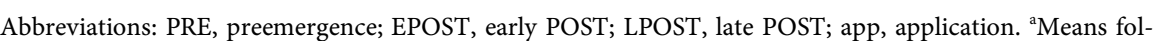
lowed by the same letter with a column are not statistically different according to Fisher's Protected LSD $(\mathrm{p}=0.05)$. ${ }^{\mathrm{b}} \mathrm{V}$ isible control estimates based on comparisons made to weedy and weed-free control treatments. 
application was applied prior to soybean canopy closure; however, the waterhemp escapes in the pyroxasulfone treatment had not reached $10 \mathrm{~cm}$ in height at the time of application.

At 2 WAA, pyroxasulfone, $S$-metolachlor/metribuzin, pyroxasulfone/sulfentrazone, and pyroxasulfone/flumioxazin applied PRE controlled GR waterhemp by $86 \%, 90 \%$, $90 \%$ and $91 \%$, respectively. Glyphosate/dicamba applied EPOST, LPOST and EPOST fb LPOST provided 85\%, 23\% and 89\% control of GR waterhemp, respectively. The sequential application of a PRE herbicide fb glyphosate/dicamba applied LPOST resulted in the same level of GR waterhemp control as the PRE herbicide applied alone (Table 3).

At 4 WAA, the PRE herbicides used alone provided $85 \%$ to $95 \%$ visible control of GR waterhemp, depending on the PRE herbicide. Glyphosate/dicamba applied EPOST, LPOST and EPOST fb LPOST provided 86\%, 65\% and 97\% visible control of GR waterhemp, respectively. All two-pass programs of a PRE herbicide fb glyphosate/dicamba LPOST provided $\geq 97 \%$ visible control of GR waterhemp, and were more efficacious than the corresponding PRE treatment alone (Table 3).

Table 3. Means for waterhemp visible control, density, biomass and soybean yield in Ontario averaged across six field sites in 2016 and $2017^{\mathrm{a}}$.

\begin{tabular}{|c|c|c|c|c|c|c|c|c|c|}
\hline \multirow[b]{2}{*}{ Treatment } & \multirow[b]{2}{*}{$\begin{array}{c}\text { Rate } \\
\left(\mathrm{g} \mathrm{ai}_{\mathrm{ae}} \mathrm{ha}^{-1}\right)\end{array}$} & \multirow[b]{2}{*}{$\begin{array}{l}\text { App. } \\
\text { Timing }\end{array}$} & \multirow[b]{2}{*}{2 WAA } & \multicolumn{3}{|c|}{ Visible control $^{\mathrm{b}}(\%)$} & \multicolumn{2}{|c|}{8 WAA } & \multirow[b]{2}{*}{$\begin{array}{c}\text { Soybean grain } \\
\text { yield } \\
\left(\mathrm{t} \cdot \mathrm{ha}^{-1}\right)\end{array}$} \\
\hline & & & & $4 \mathrm{WAA}$ & 8 WAA & $12 \mathrm{WAA}$ & $\begin{array}{c}\text { Waterhemp } \\
\text { density } \\
\left(\text { plants } \mathrm{m}^{-2} \text { ) }\right.\end{array}$ & $\begin{array}{c}\text { Waterhemp } \\
\text { biomass } \\
\left(\mathrm{g} \cdot \mathrm{m}^{-2}\right)\end{array}$ & \\
\hline Weedy control & & & 0 & 0 & 0 & 0 & $270.0 \mathrm{a}$ & $288.5 \mathrm{a}$ & $1.0 \mathrm{c}$ \\
\hline Weed-free control & & & 100 & 100 & 100 & 100 & 0 & 0 & $1.9 \mathrm{ab}$ \\
\hline Pyroxasulfone & 150 & PRE & $86 \mathrm{~d}$ & $85 c$ & $71 \mathrm{e}$ & $51 \mathrm{e}$ & $10.5 \mathrm{~d}$ & $26.2 \mathrm{bc}$ & $1.5 \mathrm{abc}$ \\
\hline$S$-metolachlor/metribuzin & 1943 & PRE & $90 \mathrm{bcd}$ & $94 \mathrm{bc}$ & $85 \mathrm{cde}$ & $75 \mathrm{~cd}$ & $4.0 \mathrm{de}$ & $18.6 \mathrm{bc}$ & $1.6 \mathrm{ab}$ \\
\hline Pyroxasulfone/sulfentrazone & 300 & PRE & $90 \mathrm{bcd}$ & $92 \mathrm{bc}$ & $82 \mathrm{de}$ & $69 \mathrm{de}$ & $4.2 \mathrm{de}$ & $19.8 \mathrm{bc}$ & $1.6 \mathrm{ab}$ \\
\hline Pyroxasulfone/flumioxazin & 240 & PRE & $91 \mathrm{bcd}$ & $95 b$ & $90 \mathrm{bcd}$ & $85 \mathrm{bcd}$ & $1.8 \mathrm{ef}$ & $10.5 \mathrm{~cd}$ & $1.3 \mathrm{bc}$ \\
\hline Glyphosate/dicamba & 1800 & EPOST & $85 \mathrm{~d}$ & $86 c$ & $77 \mathrm{de}$ & $71 \mathrm{de}$ & $30.3 c$ & $21.3 \mathrm{bc}$ & $1.4 \mathrm{abc}$ \\
\hline Glyphosate/dicamba & 1800 & LPOST & $23 e$ & $65 \mathrm{~d}$ & 79de & $69 \mathrm{de}$ & $84.9 \mathrm{~b}$ & $61.1 \mathrm{~b}$ & $1.4 \mathrm{bc}$ \\
\hline $\begin{array}{l}\text { Glyphosate/dicamba fb } \\
\text { Glyphosate/dicamba }\end{array}$ & $\begin{array}{l}1800 \\
1800\end{array}$ & $\begin{array}{l}\text { EPOST fb } \\
\text { LPOST }\end{array}$ & $89 \mathrm{~cd}$ & $97 \mathrm{ab}$ & $95 \mathrm{abc}$ & $91 \mathrm{abc}$ & $4.9 \mathrm{de}$ & 3.1edf & $1.6 \mathrm{ab}$ \\
\hline $\begin{array}{c}\text { Pyroxasulfone } \mathrm{fb} \\
\text { Glyphosate/dicamba }\end{array}$ & $\begin{array}{c}150 \\
1800\end{array}$ & $\begin{array}{l}\text { PRE fb } \\
\text { LPOST }\end{array}$ & $91 \mathrm{bcd}$ & $97 \mathrm{ab}$ & $96 a b$ & $93 \mathrm{ab}$ & $3.5 \mathrm{e}$ & $4.2 \mathrm{de}$ & $1.6 \mathrm{ab}$ \\
\hline $\begin{array}{c}S \text {-metolachlor/metribuzin fb } \\
\text { Glyphosate/dicamba }\end{array}$ & $\begin{array}{l}1943 \\
1800\end{array}$ & $\begin{array}{l}\text { PRE fb } \\
\text { LPOST }\end{array}$ & $99 \mathrm{a}$ & $99 a$ & $99 \mathrm{a}$ & $97 \mathrm{ab}$ & $0.3 \mathrm{f}$ & $0.2 \mathrm{f}$ & $2.0 \mathrm{a}$ \\
\hline $\begin{array}{c}\text { Pyroxasulfone/sulfentrazone fb } \\
\text { Glyphosate/dicamba }\end{array}$ & $\begin{array}{c}300 \\
1800\end{array}$ & $\begin{array}{l}\text { PRE fb } \\
\text { LPOST }\end{array}$ & $97 \mathrm{abc}$ & $99 a$ & $99 \mathrm{a}$ & $97 \mathrm{ab}$ & $0.6 \mathrm{f}$ & $0.6 \mathrm{ef}$ & $1.8 \mathrm{ab}$ \\
\hline $\begin{array}{c}\text { Pyroxasulfone/flumioxazin fb } \\
\text { Glyphosate/dicamba }\end{array}$ & $\begin{array}{c}240 \\
1800\end{array}$ & $\begin{array}{l}\text { PRE fb } \\
\text { LPOST }\end{array}$ & $98 \mathrm{ab}$ & $99 a$ & $99 a$ & $98 \mathrm{a}$ & $0.3 \mathrm{f}$ & $0.8 \mathrm{ef}$ & $1.8 \mathrm{ab}$ \\
\hline
\end{tabular}

Abbreviations: PRE, preemergence; EPOST, early POST; LPOST, late POST; app, application; WAA, weeks after application. ${ }^{\mathrm{a}} \mathrm{Means}$ followed by the same

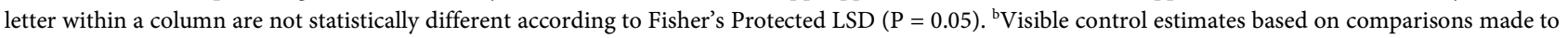
weedy and weed-free control. 
At 8 WAA, visible control of GR waterhemp with the PRE herbicides alone declined to $71 \%$ to $90 \%$ depending on the PRE herbicide. Glyphosate/dicamba applied EPOST, LPOST and EPOST fb LPOST provided 77\%, 79\% and 95\% control of GR waterhemp, respectively (Table 3). The two-pass programs of a PRE herbicide fb glyphosate/dicamba LPOST controlled GR waterhemp greater than $96 \%$ and provided greater control than the PRE herbicides alone and glyphosate/dicamba applied LPOST. There was no difference in GR waterhemp control among the two-pass programs evaluated.

At 12 WAA, visible control of GR waterhemp with the PRE herbicides alone declined to $51 \%$ to $85 \%$; the decline of control with time may be attributed to the extended waterhemp emergence waterhemp pattern [14]. Glyphosate/dicamba applied EPOST, LPOST and EPOST fb LPOST provided 71\%, 69\% and 91\% control of GR waterhemp, respectively. The two-pass programs consisting of a PRE herbicide followed by an application of glyphosate/dicamba LPOST controlled GR waterhemp $>93 \%$ and provided greater control than the PRE herbicides alone and glyphosate/dicamba applied LPOST. The less than acceptable full season control using PRE herbicides alone highlights that a two-pass program is necessary for controlling GR waterhemp through the growing season [12]. There was no difference in GR waterhemp control among the two-pass programs evaluated.

Waterhemp density and biomass of all herbicide treatments were less than the weedy control. Pyroxasulfone, $S$-metolachlor/metribuzin, pyroxasulfone/sulfentrazone, and pyroxasulfone/flumioxazin reduced GR waterhemp density and biomass by $>96 \%$ and $>91 \%$, respectively, compared to the weedy control. Glyphosate/dicamba applied EPOST, LPOST, and EPOST fb LPOST reduced GR waterhemp density by $89 \%, 68 \%$, and $98 \%$, respectively, and reduced waterhemp biomass by $92 \%, 79 \%$ and $99 \%$, respectively. The two-pass treatments consisting of a PRE residual herbicide fb glyphosate/dicamba applied LPOST reduced GR waterhemp density and biomass, $>99 \%$ and $>98 \%$, respectively. Pyroxasulfone applied PRE fb glyphosate/dicamba LPOST was not as efficacious as the other PRE herbicides evaluated.

Waterhemp interference in the weedy control reduced soybean yield $48 \%$ in this study. All treatments with herbicide(s) applied resulted in soybean yields that were similar to the weed-free control.

\section{Conclusions}

Based on this study, visible control of GR waterhemp with the four PRE herbicides evaluated declined from $>95$ at the time of the LPOST application to 51 to $85 \%$ at 12 WAA. This decline in control supports the need for effective two-pass weed control programs for the control of GR waterhemp. The two-pass programs of a residual herbicide applied PRE fb glyphosate/dicamba applied LPOST controlled GR waterhemp $\geq 93 \%$ at 12 WAA, reduced density and biomass $\geq$ $98 \%$, and resulted in soybean yields that were equivalent to the weed-free con- 
trol. Waterhemp control with a single application of glyphosate/dicamba was unacceptable; glyphosate/dicamba applied EPOST or LPOST controlled GR waterhemp $69 \%$ and $71 \%$, respectively at 12 WAA, reduced density $68 \%$ and $89 \%$ and biomass $79 \%$ and $92 \%$, respectively. Although the sequential application of glyphosate/dicamba provided $>90 \%$ control, this weed management program is not recommended due to increased selection intensity for dicamba-resistant waterhemp.

The level of visible control of glyphosate-resistant waterhemp provided by some herbicide treatments depended on the field site. At two of the sites, the PRE herbicides used alone provided $100 \%$ control throughout the season, and therefore the LPOST application of glyphosate/dicamba was not necessary.

Waterhemp is a highly prolific seed producer and even some escapes can add seed to the seedbank; therefore, season-long control is required to limit waterhemp seed return to the seedbank. The EPOST application of glyphosate/dicamba was more efficacious at 2 and 4 WAA than LPOST. At 8 and 12 WAA, there was no difference in control; however, there was a difference in density. It is important to note that the waterhemp populations at each field site were not $100 \%$ resistant to glyphosate; therefore, glyphosate was an effective mode-of-action to some degree. Crop competition is important to reduce the germination and establishment of waterhemp, therefore, narrow soybean row widths, competitive cultivars and crop rotation should be considered in a long-term diversified weed management program.

Two-pass herbicides programs provided greater than $91 \%$ control of GR waterhemp in this study. Although all two-pass systems were efficacious and there was no difference in yield, it is important to choose the most efficacious herbicide program to reduce weed seed return to the soil while also ensuring that multiple herbicide modes-of-action are used over time.

\section{Acknowledgements}

Funding for this project was provided in part by the Grain Farmers of Ontario and through the Growing Forward (GF 2) program administered by the Agricultural Adaptation Council (AAC).

\section{References}

[1] Franz, J.E., Mao, M.K. and Sikorski, J.A. (1997) Glyphosate: A Unique Global Herbicide. American Chemical Society, Washington DC.

[2] Hoss, N.E., Al-Khatib, K., Peterson, D.E. and Loughin, T.M. (2003) Efficacy of Glyphosate, Glufosinate, and Imazethapyr on Selected Weed Species. Weed Science, 51, 110-117. https://doi.org/10.1614/0043-1745(2003)051[0110:EOGGAI]2.0.CO;2

[3] Heap, I. (2018) The International Survey of Herbicide Resistant Weeds. http://www.weedscience.com

[4] Costea, M. and Tardif, F.J. (2003) Conspectus and Notes on the Genus Amaranthus in Canada. Rhodora, 105, 260-281.

[5] Schryver, M.G., Soltani, N., Hooker, D.C., Robinson, D.E., Tranel, P.J. and Sikkema, 
P.H. (2017) Glyphosate-Resistant Waterhemp (Amaranthus tuberculatus var. rudis) in Ontario, Canada. Canadian Journal of Plant Science, 97, 1057-1067. https://doi.org/10.1139/CJPS-2016-0371

[6] Schryver, M.G., Soltani, N., Hooker, D.C., Robinson, D.E., Tranel, P.J. and Sikkema, P.H. (2017) The Distribution and Control of Glyphosate-Resistant Waterhemp (Amaranthus tuberculatus var. rudis) in Soybean (Glycine max) in Ontario. M.Sc. Thesis, University of Guelph, Guelph, ON, 59-83.

[7] Schryver, M.G., Soltani, N., Hooker, D.C., Robinson, D.E., Tranel, P.J. and Sikkema, P.H. (2017) Control of Glyphosate-Resistant Common waterhemp (Amaranthus rudis) in Three New Herbicide-Resistant Soybean Varieties in Ontario. Weed Technology, 31, 828-837. https://doi.org/10.1017/wet.2017.81

[8] Hartzler, R.G., Battles, B.A. and Nordby, D. (2004) Effect of Common Waterhemp (Amaranthus rudis) Emergence Date on Growth and Fecundity in Soybean. Weed Science, 52, 242-245. https://doi.org/10.1614/WS-03-004R

[9] Vyn, J.D., Swanton, C.J., Weaver, S.E. and Sikkema, P.H. (2007) Control of Herbicide-Resistant Common Waterhemp (Amaranthus tuberculatus var. rudis) with Preand Post-Emergence Herbicides in Soybean. Canadian Journal of Plant Science, 87, 175-182. https://doi.org/10.4141/P06-016

[10] Steckel, L.E., Sprague, C.L., Hager, A.G., Simmons, F.W. and Bollero, G.A. (2003) Effects of Shading on Common Waterhemp (Amaranthus rudis) Growth and Development. Weed Science, 51, 898-903. https://doi.org/10.1614/P2002-139

[11] Hay, M.M. (2017) Control of Palmer Amaranth (Amaranthus palmeri) and Common Waterhemp (Amaranthus rudis) in Double Crop Soybean and with Very Long Chain Fatty acid Inhibitor Herbicides. M.Sc. Thesis, Kansas State University, Manhattan, KS, $72 \mathrm{p}$.

[12] Sarangi, D., Sandell, L.D., Kruger, G.R., Knezevic, S.Z., Irmak, S. and Jhala, A.J. (2017) Comparison of Herbicide Programs for Season-Long Control of Glyphosate-Resistant Common Waterhemp (Amaranthus rudis) in Soybean. Weed Technology, 31, 53-66. https://doi.org/10.1017/wet.2016.1

[13] Spaunhorst, D.J. and Bradley, K.W. (2013) Influence of Dicamba and Dicamba Plus Glyphosate Combinations on the Control of Glyphosate-Resistant Waterhemp (Amaranthus rudis). Weed Technology, 27, 675-681. https://doi.org/10.1614/WT-D-13-00081.1

[14] Smith, A.E. (1973) Degradation of Dicamba in Prairie Soils. Weed Research, 13, 373-378. https://doi.org/10.1111/j.1365-3180.1973.tb01289.x 